\title{
Translational capacity of sheep oocytes microinjected with messenger RNA
}

\author{
R. M. Moor and D. J. Powell \\ Department of Molecular Embryology, Institute of Animal Physiology and Genetics Research, \\ Babraham, Cambridge CB2 4AT, UK
}

\begin{abstract}
Summary. Sheep oocytes were microinjected with tobacco mosaic virus RNA (TMVRNA) and isotopically labelled with $\mathrm{L}-\left[{ }^{35} \mathrm{~S}\right]$ methionine. Total incorporation of labelled methionine was similar in TMV-RNA-injected and in carrier-injected control oocytes, whether injections were performed during the period of high protein synthesis at maturation or during the period of reduced synthesis at a time equivalent to the mid-cleavage transition ( $48 \mathrm{~h}$ after germinal vesicle breakdown). Varying the amount of TMV-RNA injected from $2 \cdot 5$ to $10 \mathrm{pg}$ had little effect on the overall level of amino acid incorporation. Furthermore TMV-RNA appeared to be very stable in oocytes and eggs; the proportion of total polypeptide synthesisdirected by TMV-RNA did not diminish during the first $48 \mathrm{~h}$ after injection. Synthesis of most endogenous proteins was uniformly reduced to compensate for the synthesis of TMV-polypeptides. Our results suggest, therefore, that the translational capacity of sheep oocytes is fully saturated during maturation.
\end{abstract}

Keyu'ords: oocyte; mRNA translation; mRNA stability

\section{Introduction}

Post-transcriptional control mechanisms regulate protein synthesis in oocytes at fertilization and in embryos during the first cleavage divisions (Davidson, 1976; Johnson, 1981). Subsequently, maternal messenger RNA (mRNA) translation declines and a major wave of transcriptional activity signals the onset of embryonic genetic activity. The means by which these post-transcriptional controls are imposed differ at the various stages of early embryonic development in mammals. In oocytes, reprogramming of protein synthesis involves the translation of stored mRNA and the post-translational modification of newly synthesized proteins (reviewed by Wasserman et al., 1981). The mechanisms involved in the translation of stored $\mathrm{mRNA}$ raise a number of interesting questions including that of the inherent capacity of the oocyte to translate new $\mathrm{mRNA}$ as it becomes available during maturation.

Microinjection of mRNA into amphibian oocytes has provided important information on the translational capacity of these cells (Lane \& Knowland, 1975; Laskey et al., 1977; Richter \& Smith, 1981, 1984). In mammals it has been shown that mouse eggs will translate microinjected $m$ RNA and that the protein product can be exported (Brinster et al., 1980, 1981). More recently Ebert \& Brinster (1983) reported that the injection of $\alpha$ globin m RNA neither altered total protein synthesis nor affected the translation of endogenous mRNA in fertilized mouse eggs.

In the present experiments we report on the translational capacity of sheep oocytes during the phase of maturation that immediately precedes the translation of stored maternal mRNA.

\section{Materials and Methods}

Preparation and injection of oocytes. Oocytes were obtained from non-atretic follicles dissected from the ovaries of FSH-treated sheep. Before microinjection all but the last 2 or 3 layers of associated follicle cells were removed from 
each oocyte using a series of accurately graded micropipettes. The medium in which the oocytes were held during microinjection consisted of phosphate-buffered saline (PBS: Paul, 1970) supplemented with BSA (4 mg/ml), cytochalasin-D $(5 \mu \mathrm{g} / \mathrm{ml})$ sodium pyruvate $(0.4 \mathrm{~mm})$ and kanamycin sulphate $(50 \mu \mathrm{g} / \mathrm{ml})$. After injection all oocytes were washed repeatedly ( 5 times) in the PBS medium devoid of cytochalasin D before culture.

Micropipettes were pulled to a uniform size (P-77 Brown-Flaming microelectrode puller), bevelled, oil-filled and autoclaved before use to eliminate RNase contamination. Injections were carried out on oocytes maintained in hanging drops in an oil-filled microinjection chamber. The volume of fluid injected was calculated from a calibration curve constructed by correlating the length of columns of fluid in different micropipettes with their volume using tracer dilution techniques. With standardized pipettes this system provides a rapid and accurate means of volume measurement during injection since the length of the column of medium in the pipette can be continuously monitored using a calibrated eye-piece. Moreover, by expelling a known length of fluid under oil and measuring the diameter of the resultant droplet, adjustments can be made for each pipette before use. The volumes of fluid injected into the cytoplasm of oocytes in this study ranged from $2 \cdot 5-10 \mathrm{pl}$.

In preliminary experiments mRNAs of mammalian (globin), plant ( $\alpha$ amalyase) and viral (Avian influenza $A$ and Tobacco Mosaic Virus) origin were tested by microinjection into oocytes. Although each mRNA species was translated by the oocytes, TMV-RNA was selected primarily because it coded for a major polypeptide which was readily distinguished from all endogenous oocyte polypeptides. Moreover, the TMV-RNA used in our experiments (generously provided by Dr T. Hunt, University of Cambridge) was of particularly high quality and integrity when tested by in-vitro translation using the reticulocyte lysate system. The TMV-RNA was stored in sealed glass capillaries under liquid nitrogen.

Isotopic labelling, fractionation and quantitation of proteins. Oocytes were divided into two groups after injection. One group was cultured for $36 \mathrm{~h}$ (Staigmiller \& Moor, 1984) before being labelled. These oocytes were at metaphase II when $L-\left[{ }^{35} S\right]$ methionine was added. The second group of oocytes was placed in label directly after microinjection and before germinal vesicle breakdown had occurred. Both groups were labelled for $12 \mathrm{~h}$ in incubation medium containing $500 \mu \mathrm{Ci} \mathrm{L}-\left[{ }^{35} \mathrm{~S}\right]$ methionine/ml (sp. act. $>1000 \mathrm{Ci} / \mathrm{mmol}$ : Radiochemical Centre, Amersham, Bucks, UK).

After incubation, single oocytes were totally denuded of follicle cells, washed extensively and collected in $2 \mu \mathrm{l}$

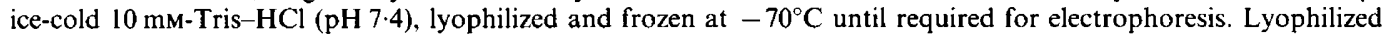
samples were resuspended in $30 \mu \mathrm{l}$ of sample buffer ( $\mathrm{O}^{\prime}$ Farrell, 1975), heated to $100^{\circ} \mathrm{C}$ and $3 \mu \mathrm{l}$ samples were used to measure $\mathrm{L}-\left[{ }^{35} \mathrm{~S}\right]$ methionine incorporation into TCA-precipitable protein. Parallel incorporation measurements showed that a negligible proportion of the incorporated radioactivity was soluble in TCA at $90^{\circ} \mathrm{C}$ but insoluble at $0^{\circ} \mathrm{C}$.

Labelled proteins in individual samples were resolved by applying equal numbers of TCA-precipitable counts to an $8-15 \%$ linear gradient SDS polyacrylamide gel using the discontinuous SDS-glycine-Tris buffer system of Laemmli (1970). Fluorography was carried out using the technique of Bonner \& Laskey (1974). After drying, gels

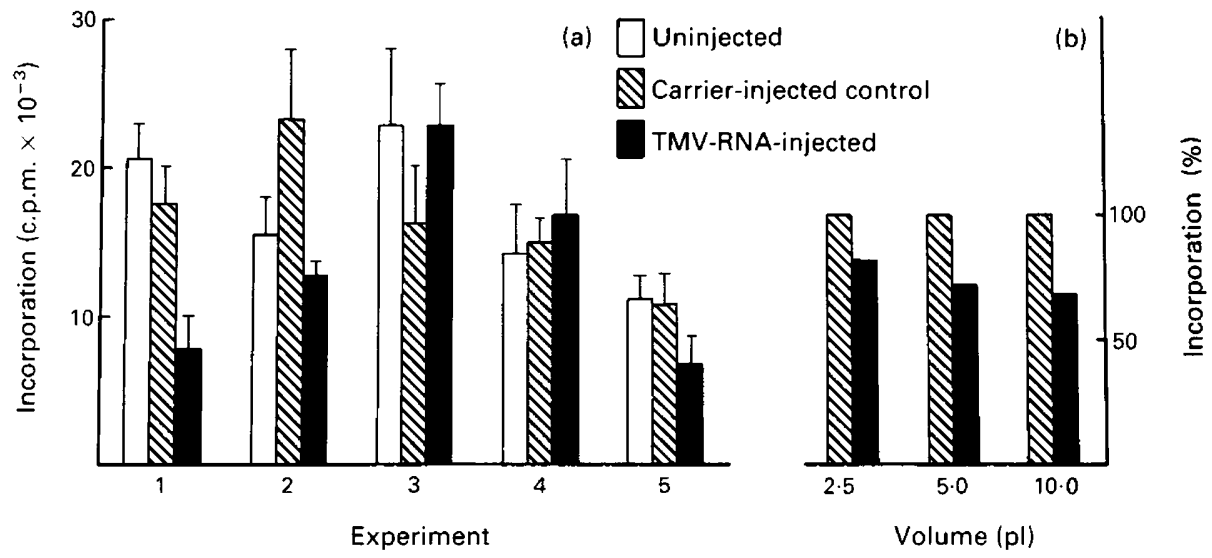

Fig. 1. Incorporation of $\mathrm{L}-\left[{ }^{35} \mathrm{~S}\right]$ methionine into sheep oocytes injected with TMV-RNA $(1 \mathrm{mg} / \mathrm{ml})$ at the beginning of maturation. (a) Total incorporation $( \pm$ s.e.m.) in individual oocytes labelled, after injection, for $12 \mathrm{~h}$ in $\mathrm{L}-\left[{ }^{35} \mathrm{~S}\right]$ methionine. Each separate experiment has three groups of 10-20 oocytes which represent an uninjected control group, carrier-injected control group, a TMV-RNA injected group (10 pg TMV-RNA/oocyte). (b) The effect of varying the volume of TMV-RNA $(1 \mathrm{mg} / \mathrm{ml})$ on the incorporation of methionine during the first $12 \mathrm{~h}$ after injection. To illustrate the trend towards a reduction in incorporation the results in TMV-RNA injected oocytes are expressed as a percentage of total incorporation in controls injected with an equal volume of carrier alone. 


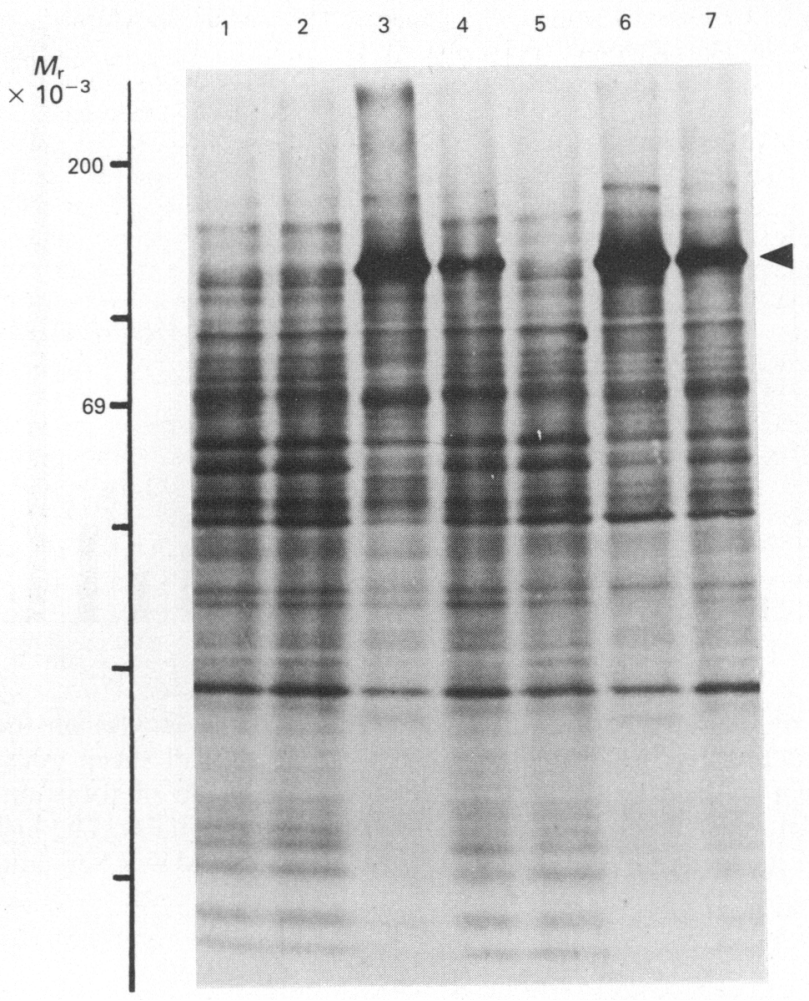

Fig. 2. Fluorogram of ${ }^{35} \mathrm{~S}$-labelled polypeptides from individual carrier-injected (tracks 1 and 2) and TMV-RNA-injected oocytes (tracks 3-7). Oocytes were injected with $10 \mathrm{pl}$ carrier or TMV-RNA $(1 \mathrm{mg} / \mathrm{ml})$. They were then labelled for $12 \mathrm{~h}$ in the presence of $500 \mu \mathrm{Ci} / \mathrm{ml}$ $\mathrm{L}-\left[{ }^{35} \mathrm{~S}\right]$ methionine, and run on $8-15 \%$ SDS-gradient gels as described in the 'Methods'. Equal numbers of TCA-precipitable counts were loaded onto each track of the gel. The oocyte in track 5 failed to translate the injected TMV-RNA; such oocytes have been excluded from further analysis. The major TMV polypeptide $\left(M_{\mathrm{r}}=110000\right)$ is indicated by an arrow head.

were exposed to Kodak X-Omat-S film which had been hypersensitized by pre-exposure to a $1 \mathrm{msec}$ flash of light to achieve an absorbance increment of 0.15 (Laskey \& Mills, 1975). Films were exposed at $-70^{\circ} \mathrm{C}$ and after development were scanned using a Helena Quickscan R \& D densitometer interfaced to an Apple II microcomputer. After an automatic adjustment to background signal the computer programme resolves peaks by identifying minima in the data (Crosby, 1982). The peaks are marked and the area under each peak is calculated as a percentage of the total. The validity of this quantitative approach has been discussed in detail by Laskey \& Mills (1975).

\section{Results}

\section{Effect of exogenous $m R N A$ on amino acid incorporation}

Laskey et al. (1977) demonstrated that globin mRNA injected into Xenopus oocytes slightly reduces overall incorporation of $\mathrm{L}-\left[{ }^{35} \mathrm{~S}\right]$ methionine into total TCA precipitable protein. The results summarized in Fig. 1 show that a similar effect on methionine incorporation was obtained when TMV-RNA was injected into mammalian oocytes. Injection of a constant amount of mRNA reduced incorporation in one experiment $(P<0.05)$ but was without significant effect in the remaining 4 experiments (Fig. 1a).

The amount of RNA injected was varied over a 5-fold range; the incorporation in RNAinjected and buffer-injected control oocytes did not differ significantly (Fig. 1b). However, the 


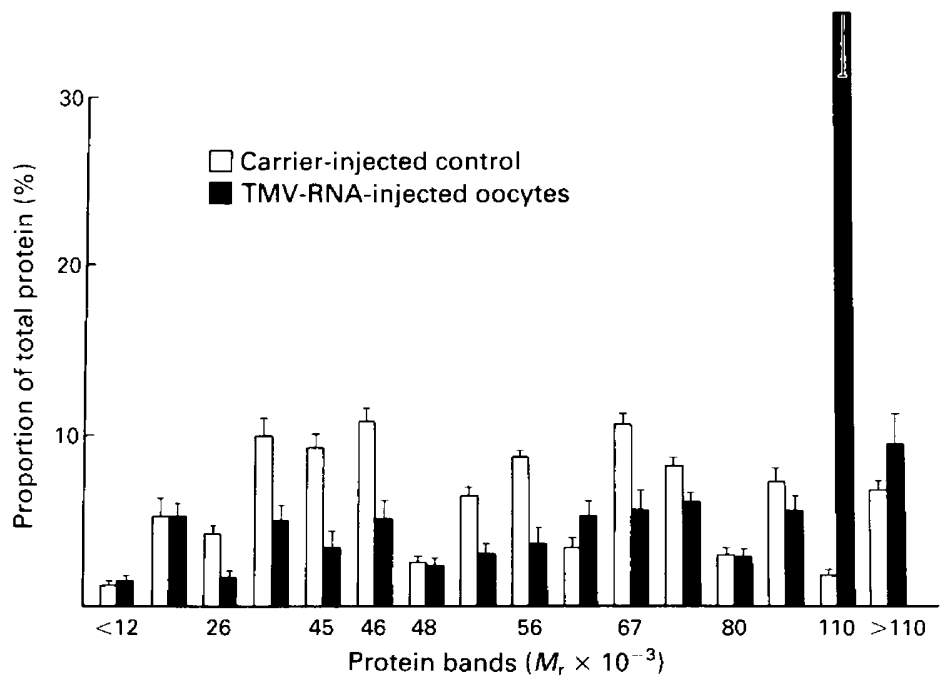

Fig. 3. Analysis of the effect of injecting TMV-RNA (10 pg/oocyte) on the electrophoretic profile of labelled proteins in individually injected and control sheep oocytes. The relative amount of protein in each band is expressed as a percentage of total amount of labelled protein loaded onto each track (see Fig. 2 for experimental details). The histogram has been constructed from an analysis of 20 oocytes in each of the TMV-RNA- and carrier-injected groups.

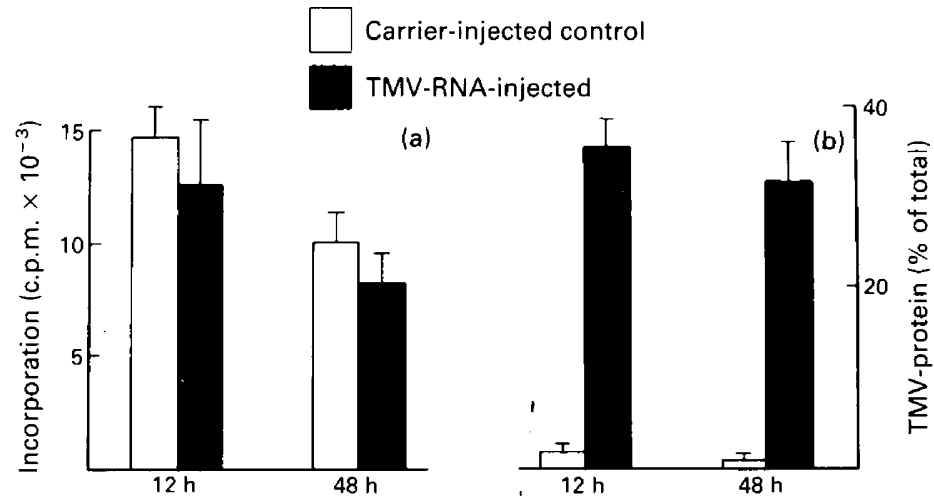

Fig. 4. The comparative stability of TMV-RNA measured by its capacity to code for the major viral polypeptide $\left(M_{\mathrm{r}} 110000\right)$ during the first $12 \mathrm{~h}$ or between 36 and $48 \mathrm{~h}$ after injection into sheep oocytes. Oocytes were injected with TMV-RNA $(10 \mathrm{pg})$ or carrier and labelled directly in $\mathrm{L}-\left[^{35} \mathrm{~S}\right] \mathrm{methionine}(12 \mathrm{~h}$ group) or cultured for $36 \mathrm{~h}$ before isotopic labelling for an equivalent period of time ( $48 \mathrm{~h}$ group).

reported trend (Laskey et al., 1977) towards a lower rate of amino acid incorporation in mRNA-injected Xenopus oocytes was also apparent in mammalian oocytes within $12 \mathrm{~h}$ of injection.

\section{Synthesis of protein in $m R N A$-injected oocytes}

The profile of labelled proteins in oocytes injected with carrier or TMV-RNA is shown in Fig. 2. The effect of exogenous mRNA on the synthesis of endogenous proteins has been analysed by densitometry and these quantitative results are presented in Fig. 3. Synthesis of the dominant 
encoded protein of $M_{\mathrm{r}} 110000$ was accompanied by a significant decline in the synthesis of most classes of endogenous proteins. However, synthesis of a small number of endogenous proteins remained unaffected by exogenous mRNA translation. Several possible explanations for these unaltered rates of synthesis are discussed below.

To examine the possibility that exogenous mRNA competes with endogenous mRNA only above a certain threshold level, different amounts of TMV-RNA were injected into oocytes (2.5-10 pg mRNA per oocyte). The results, which were similar to those in Fig. 2, indicated that, at each of these concentrations of mRNA, synthesis of TMV proteins was accompanied by a decline in the synthesis of endogenous proteins.

\section{Stability of TMV RNA in oocytes}

Brinster et al. (1980) reported that the half-life of $\alpha$-globin mRNA in mouse eggs is short (about $9 \mathrm{~h}$ ) and hence differed greatly from that in Xenopus oocytes (>2 weeks; Gurdon et al., 1973). In the current series of sheep oocyte injection experiments, we found that stability of TMV-RNA was much greater than that found for globin mRNA in mouse eggs. Figure 4(a) shows that the total amount of labelled methionine incorporated into control and TMV-RNA-injected eggs was high during maturation but by $48 \mathrm{~h}$ started to decline in a manner similar to that described by Crosby et al. (1988) for cleaving embryos. However, the results presented in Fig. 4(b) show that the proportion of total protein synthesis represented by the TMV polypeptide of $M_{\mathrm{r}} 110000$ was very similar, irrespective of whether oocytes were examined $12 \mathrm{~h}$ or $48 \mathrm{~h}$ after injection with TMV-RNA. It is therefore clear that TMV-RNA is relatively stable in sheep oocytes and unfertilized eggs.

\section{Discussion}

It has been firmly established that amphibian oocytes and eggs can translate a wide variety of mammalian and viral mRNAs (Lane, 1981). It is now clear that mammalian oocytes, eggs and embryos can be similarly undiscriminating in their ability to translate mRNA without regard to species, phylum or even kingdom of the donor organism. Brinster et al. $(1980,1981)$ provided evidence to show that fertilized mouse eggs effectively translate mRNA from a variety of mammalian species. In our current experiments we found that sheep oocytes, eggs and embryos translate both viral and plant mRNAs ( $\alpha$-amylase: R. M. Moor, unpublished observations).

In the present experiments TMV-RNA is stable in the sheep oocyte for a period of at least $48 \mathrm{~h}$, and must compete with the existing cellular mRNAs for a limited protein synthetic capacity (see below). Published work on other mammalian species has concentrated on the fertilized mouse egg (Brinster et al., 1980; Chen \& Brinster, 1982), which, like the sheep oocyte, appears to have little if any spare translational capacity (Ebert \& Brinster, 1983). Globin mRNA is unstable in the fertilized mouse egg, displaying a half life of about $9 \mathrm{~h}$ and becoming undetectable at $48 \mathrm{~h}$ after injection (Brinster et al., 1980; Chen \& Brinster, 1982). This observation, however, probably results from the switch in gene expression that occurs at the 2-cell stage in the mouse, when embryonic mRNAs are synthesized and maternal mRNAs, presumably together with injected globin mRNA, are degraded. Preliminary data indicate that TMV-RNA is stable in fertilized sheep eggs for over $50 \mathrm{~h}$ and probably also persists until the switch from maternal to embryonic gene expression which occurs between the 8- and 16-cell stage (Crosby et al., 1988).

Our results do, however, bear comparison with those obtained in the Xenopus oocyte. First, we find that the injected mRNA is very stable, insofar as the rate of translation of the injected mRNA changes only slightly during a $48 \mathrm{~h}$ culture period. Furthermore, mRNA injected into sheep oocytes or into amphibian oocytes caused a decline in endogenous protein synthesis. It therefore appears that in both systems injected mRNA is translated only because it competes directly with endogenous mRNA. In Xenopus, it has been established that this competition is for a limiting component which is not associated with peptide chain initiation but rather is a component of 
polysomes (Lingrel \& Woodland, 1974; Laskey et al., 1977). Our findings are fully consistent with the concept that the sheep oocyte translation capacity is normally fully saturated.

Our results also clearly indicate that the translation of the majority of endogenous mRNA species is uniformly reduced by the oocyte to enable it to translate the newly injected TMV-RNA. During maturation, when the oocyte is similarly exposed to a large quantity of new, endogenous mRNA, about $30 \%$ of the total pool of stored maternal mRNA is released during a short period of early metaphase (M-phase) of the cell cycle and becomes available for translation (Bacharova et al., 1985). As with the injected oocyte, there is little change in the overall rate of polypeptide synthesis. However, a clear difference between the two systems is in the selectivity displayed by the maturing oocyte. While the TMV-injected oocytes respond by uniformly reducing translation of most RNAs, in the maturing oocyte translation of some mRNA species ceases almost entirely while translation of others remains unaffected by the newly liberated maternal mRNA (Wasserman et al., 1981; Moor \& Crosby, 1986). One of the clearest examples of this selectivity is the cessation of actin synthesis during reprogramming events in the M-phase oocyte (see Moor \& Osborn, 1983). Moreover, experiments on the mechanism of selectivity within the oocyte indicate that the surrounding follicle cells play a directive role in the translation of actin mRNA. This characteristic selectivity applies also to amphibians in which oocytes display a more defined specificity for the translation of endogenous as compared to exogenous mRNA.

How might such selectivity be effected? The failure of TMV-RNA to compete with a small number of endogenous mRNAs may be caused by the high efficiency of translation of these mRNAs as a result of their affinity for some component of the translation apparatus (for a discussion see Lodish, 1976). Although the availability of ribosomes is reduced such mRNAs would still compete well for the limited resources (Laskey et al., 1977). An alternative explanation is that the TMV-resistant RNAs are in a privileged environment: membrane-bound and free polysomes form separate compartments and there is no competition between mRNAs in each compartment (Richter \& Smith, 1981). We have not yet performed the competition experiments required to distinguish between these explanations, but such studies are now possible.

Developmental changes in mRNA translatability are well established in invertebrate (Powell et al., 1984; Ruzdijic \& Pedersen, 1987; Rosenthal \& Ruderman, 1987) and vertebrate (Gurdon et al., 1973; Woodland \& Wilt, 1980; Kidder \& Pedersen, 1982; Galili et al., 1988) systems. It appears that long poly(A) tails are required to stimulate both translation and stability of mRNA during early development of the surf clam, Spisula (Rosenthal \& Ruderman, 1987). Galili et al. (1988) reached a similar conclusion by microinjecting mRNA into Xenopus oocytes. Moreover, sequences within the body of the mRNA, such as the AU-rich sequence found in many short-lived mRNAs, may be partly responsible for defining turnover rates (Merill et al., 1984; Shaw \& Kamen, 1986; Graves et al., 1987). It would be of interest to determine whether the instability detected in the cultured cells in these experiments by the addition of AU-rich sequences operates in the oocyte or whether the special nature of translational control in the oocyte involves other mechanisms.

Purified hormones were a generous gift from the National Institutes of Arthritis, Metabolism and Digestive Diseases, National Institutes of Health, Bethesda MD. Microinjection equipment was purchased with grants from Life Force Research and the Smithkline Foundation. We thank Mrs L. Notton for typing the manuscript.

\section{References}

Bachvarova, R., De Leon, V., Johnson, A., Kaplan, G. \& Paynton, V. (1985) Changes in total RNA, polyadenylated RNA and actin mRNA during meiotic maturation of mouse oocytes. Devl Biol. 108, 325-331.
Bonner, W.M. \& Laskey, R.A. (1974) A film detection method for tritium labelled proteins and nucleic acids in polyacrylamide gels. Eur. J. Biochem. 46, 83-88. 
Brinster, R.L., Chen, H.Y., Trumbauer, M.E. \& Avarbock, M.R. (1980) Translation of globin messenger RNA by the mouse ovum. Nature, Lond. 283, 499-501.

Brinster, R.L., Chen, H.Y., Trumbauer, M.E. \& Paynton, B.V. (1981) Secretion of protein by the fertilized mouse ovum. Expl Cell Res. 134, 291-296.

Chen, H.Y. \& Brinster, R.L. (1982) Stability of rabbit globin and its messenger RNA in the mouse ovum. Expl Cell Res. 141, 469-473.

Crosby, I.M. (1982) Apple analysis of scanning densitometry data. Biochemistry Microcomputer Group 6, $7-12$.

Crosby, I.M., Gandolfi, F. \& Moor, R.M. (1988) The control of protein synthesis during early cleavage of sheep embryos. J. Reprod. Fert. 82, 769-775.

Davidson, E.H. (1976) Gene Activity in Early Development, 2nd edn. Academic Press, New York.

Ebert, K.M. \& Brinster, R.L. (1983) Rabbit $\alpha$-globin messenger RNA translated by the mouse ovum. $J$. Embryol. exp. Morph. 74, 159-168.

Galili, G., Kawata, E.E., Smith, L.D. \& Larkins, B.A. (1988) Role of the 3'-poly (A) Sequence in translational regulation of mRNAs in Xenopus laevis oocytes. J. biol. Chem. 263, 5764-5770.

Graves, R.A., Pandey, N.B., Chedchoy, N. \& Margluff, W.F. (1987) Translation is required for histone mRNA degradation. Cell 48, 615-626.

Gurdon, J.B., Lingrel, J.B. \& Marbaix, G. (1973) Message stability in injected frog oocytes: long life of mammalian and globin messages. J. molec. Biol. 80, 539-551.

Johnson, M.H. (1981) The molecular and cellular basis of preimplantation mouse development. Biol. Rev. 56, 463-498.

Kidder, G.M. \& Pedersen, R.A. (1982) Turnover of embryonic messenger RNA in preimplantation mouse embryos. J. Embryol. exp. Morph. 67, 37-49.

Laemmli, U.K. (1970) Cleavage of structural proteins during the assembly of the head of bacteriophage T4. Nature, Lond. 227, 680-685.

Lane, C.D. (1981) The fate of foreign proteins introduced into Xenopus oocytes. Cell 24, 281-282.

Lane, C.D. \& Knowland, J.S. (1975) The injection of RNA into living cells: the use of frog oocytes for the assay of mRNA and the study of the control of gene expression. In Biochemistry of Animal Development, Vol. 3, pp. 145-181. Ed. R. Weber. Academic Press, New York.

Laskey, R.A. \& Mills, A.D. (1975) Quantitative detection of ${ }^{3} \mathrm{H}$ and ${ }^{14} \mathrm{C}$ in polyacrylamide gels by fluorography. Eur. J. Biochem. 56, 335-341.

Laskey, R., Mills, A., Gurdon, J. \& Partington, G. (1977) Protein synthesis in oocytes of Xenopus laevis is not regulated by the supply of messenger RNA. Cell 11, 345-351.

Lingrel, J. \& Woodland, H. (1974) Initiation does not limit the rate of globin synthesis in message-injected Xenopus oocytes. Eur. J. Biochem. 47, 47-56.
Lodish, H.F. (1976) Translational control of protein synthesis. Ann. Rev. Biochem. 45, 39-72.

Merrill, G.F., Haisschka, S.D. \& McKnight, S.L. (1984) tk enzyme expression in differentiating muscle cells is regulated through an internal segment of the tk gene. Molec. cell Biol. 4, 1777-1784.

Moor, R.M. \& Crosby, I.M. (1986) Protein requirements for germinal vesicle breakdown in ovine oocytes. $J$. Embryol. exp. Morph. 94, 207-220.

Moor, R.M. \& Osborn, J.C. (1983) Somatic control of protein synthesis in mammalian oocytes during maturation. In Molecular Biology of Egg Maturation (Ciba Fdn Symp. No. 98), pp. 178-196. Pitman, London.

O'Farrell, P.H. (1975) High resolution two-dimensional electrophoresis of proteins. J. biol. Chem. 250, 4007-4021.

Paul, J. (1970) Cell and Tissue Culture, 4th edn. E. \& S. Livingstone, Edinburgh.

Powell, D., Sato, J.D., Brock, H.W. \& Roberts, D.B. (1984) Regulation of synthesis of the larval serum proteins of Drosophila melanogaster. Devl Biol. 102, 206-215.

Richter, J.D. \& Smith, L. (1981) Differential capacity for translation and lack of competition between mRNAs that segregate to free and membrane-bound polysomes. Cell 27, 182-191.

Richter, J.D. \& Smith, L.D. (1984) Reversible inhibition of translation by Xenopus oocyte-specific proteins. Nature, Lond. 309, 378-380.

Rosenthal, E.T. \& Ruderman, J.V. (1987) Widespread changes in the translation and adenylation of maternal messenger RNAs following fertilization of Spisula oocytes. Devl Biol. 121, 237-246.

Ruzdijic, S. \& Pedersen, R.A. (1987) Evidence for an association between UI RNA and interspersed repeat single-copy RNAs in the cytoplasm of sea urchin eggs. Development 101, 107-116.

Shaw, G. \& Kamen, R. (1986) A conserved AU sequence from the $3^{\prime}$ untranslated region of GM-CSF mRNA mediates selective mRNA degradation. Cell 46, 659-667.

Staigmiller, R.D. \& Moor, R.M. (1984) Effect of follicle cells on the maturation and developmental competence of ovine oocytes matured outside the follicle. Gamete Res. 9, 221-229.

Wassarman, P.M., Bleil, J.D., Cascio, S.M., La Marca, M.J., Letourneau, G.E., Mrozak, S.C. \& Schultz, R.M. (1981) Programming of gene expression during mammalian oogenesis. In Bioregulators of Reproduction, pp. 119-150. Eds G. Jagiello \& H. J. Vogel. Academic Press, New York.

Woodland, H.R. \& Wilt, F.H. (1980) The stability and translation of sea urchin histone messenger RNA molecules injected into Xenopus laevis eggs and developing embryos. Devl Biol. 75, 214-221.

Received 12 September 1988 